Common Crow. Several other species of passerines listed by him may also be "accidental hosts." In addition, Hatch (1967) provides a substantiated record for the Common Crow.

\section{LITERATURE CITED}

Bent, A. C. 1932 (Dover edition 1963). Life histories of North American gallinaceous birds. U.S. Nat. Mus. Bull. 162.

Bent, A. C. 1958 (Dover edition 1965). Life histories of North American blackbirds, orioles, tanagers, and allies. U.S. Nat. Mus. Bull. 211.

Berger, A. J. 1951. The cowbird and certain host species in Michigan. Wilson Bull., 63: 26-34.
Friedmann, H. C. 1963. Host relations of the parasitic cowbirds. U.S. Nat. Mus. Bull. 233.

Hatch, D. R. M. 1967. Cowbird egg in crow nest. Blue Jay, $25: 189$.

Houston, C. S. 1966. Book review of "Host relations of the parasitic cowbirds" by Herbert Friedmann, 1963. Blue Jay, 24:44.

King, J. R. 1954. Victims of the Brown-headed Cowbird in Whitman County, Washington. Condor, $56: 150-154$.

Norris, R. T. 1947. The cowbirds of Preston Frith. Wilson Bull., $59: 83-103$.

Terril, L. M. 1961. Cowbird host in southern Quebec. Canadian Field-Nat., $75: 2-11$.

Walkinshaw, L. H. 1949. Twenty-five eggs apparently laid by one cowbird. Wilson Bull., $61: 82-85$.

\title{
BANK SWALLOWS IN GRAVEL STOCK-PILES IN MANITOBA
}

by Robert W. Nero, Manitoba Museum of Man and Nature, 147 James Ave., Winnipeg 2, Manitoba

The use of gravel stock-piles by Bank Swallows for nesting sites has been recorded for nine localities in Saskatchewan (Blue Jay, 19:20, 84, 115,$174 ; 22: 42$ ), but has evidently not previously been reported for Manitoba. I found an active colony on August 12, 1967 about 18 miles east of Winnipeg where several gravel stockpiles lie adjacent to water-filled excavations on the north side of highway No. 15. Fifty-three apparently active nest burrows were found in a large stock-pile and on a southwest-facing embankment about 12 feet high and 25 feet long. Broken eggs and dead newly-hatched young lying on the slope beneath the face of the embankment had clearly resulted from nests being dug out a few days earlier by vandals. Incubation was evidently still in progress, since several adults were flushed from the burrows a long time after the flock had been milling. about us. This is a late date for nesting for this species which, in Manitoba, normally has begun to migrate by the third week in August. The material in this stock-pile was a very compact, fine, sandy gravel, almost a coarse sand.
An older, abandoned colony site with about 100 nest burrows was found on a west-facing cut on a nearby pile. A third pile was of some interest in that in contrast with the other piles which were devoid of vegetation it had a few clumps of sowthistle, Canada thistle, and chokecherry on top. Gravel had not yet been removed from this pile, hence it offered only gentle slopes in which burrow excavation would not be possible. Bank Swallow nesting sites seem to require a nearly vertical face. The removal of sand or gravel from a stock-pile of suitably compacted material results in the formation of such an embankment. Later slumping may improve the site by forming a new and better face or it may demolish the colony, depending upon the timing. Nesting also requires a cessation of gravel removal operations following the initial establishment of a cut. These several factors may only occasionally be met, but it is clear that Bank Swallows are especially adapted to taking advantage of transitory cutbanks, not only along streams and in excavations but also in the wholly artificial situation of sand and gravel stock-piles. 